\title{
Improving Organizational Citizenship Behavior (OCB) Through Servant Leadership and Job Satisfaction
}

\author{
Dian Wulandari*, Widodo Sunaryo, Sumardi \\ Education Administration, Post-graduate School \\ Pakuan University \\ Bogor, Indonesia \\ *dianwulandari@unpak.ac.id
}

\author{
Dewi Indrajanti Tedjasukmana \\ Vocational School \\ IPB University \\ Bogor, Indonesia \\ tedjasukmana.dewi@gmail.com
}

\begin{abstract}
There is no teacher without an extra role, especially in an uncertain condition; therefore, all principals need to know how to improve the teacher's OCB. The study's aim is to examine the indicators that have the strongest impact on Private Junior High School Teacher's OCB at Bogor, West Java. This research focused on factors of servant leadership and job satisfaction that can have a significant influence on OCB. The correlational analysis showed that there is a moderate positive relationship $(r=0.549, \rho<0.01)$ between Servant Leadership and OCB, and Job Satisfaction with OCB $(\mathrm{r}=0.433, \rho<0.01)$. By SITOREM (Scientific Identification Theory to Conduct Research in Education Management) analysis, it found several indicators from that should be improved immediately are: build community, provide leadership, value people, display authentic, salary, promotion opportunities, supervision, sportsmanship, altruism, civic virtue, and conscientiousness.
\end{abstract}

Keywords-job satisfaction, Organizational Citizenship Behavior (OCB), servant leadership

\section{INTRODUCTION}

All school management must make efforts to improve the Organizational Citizenship Behavior (OCB) of teachers. A high score on OCB is one of the indicators that teachers can become excellent quality educators. They are responsible for the organization and willing to help colleagues who get into problems. OCB is a sincere and voluntary individual contribution beyond the assigned role's demands without expecting a reward. This behavior can positively affect organizational effectiveness and does not result in additional expenses, for example, for overtime pay. OCB also contains an understanding of sincerity in accepting in appropriate circumstances, the behavior of maintaining good relations with colleagues, and the behavior of developing self-potential optimally.

Previous research conducted by Maulana, examines OCB as an independent variable related to the work quality [1]. Likewise, Suzana's study examined OCB as an independent variable associated with performance. [2]. Both kinds of research treat $\mathrm{OCB}$ as independent variables. The field shows that OCB is so important and decisive in schools' success in achieving its goals. It is also essential to find a strategy to increase $\mathrm{OCB}$ by studying factors related to it, definite indicators that have significant leverage to increase OCB.

Based on a preliminary survey, it found that teachers' OCB is not as expected. They were still the problem at altruistic behavior $(64 \%)$, a conscientious problem $(54 \%)$, altruistic (47\%), sportsmanship behavior (47\%), courtesy behavior $(46 \%)$, and $38 \%$ still have civic virtue behavior problems. Teachers 'OCB can influence by principals' Servant Leadership, Job Satisfaction, Interpersonal Communication, Emotional Intelligence, Organizational Culture, Work Motivation, and other factors. This study limits to find efforts and strategies to increase OCB through Servant Leadership and Job Satisfaction, individually or collectively.

OCB is a behavior that goes beyond the call of duty, is a set of discretionary workplace behavior that exceeds one's essential job requirement. OCB is not written in the work contract and rules between individuals and organizations but is carried out voluntarily at the individual's own will. If it is not, it will not receive any sanctions from the organization. OCB cannot be imposed, and does not expect rewards, but can improve the organization's quality where the individual works.There are five main factors: (1) Altruism, helping coworkers in work assignment problem, (2) conscientiousness; individual voluntary behavior that exceeds the minimum standards in the organization such as attendance, compliance, behavior related to self-discipline, responsibility, and hard work, (3) sportsmanship, individual behaviour to tolerate without complaining to less than ideal circumstance in organization, (4) courtesy is the behaviour of individuals who try to avoid conflicts with a colleague, to maintain good relations with colleagues to create a peaceful work environment, and (5) civic virtue shows the behaviour of individuals who are willing to involve themselves in organizational activities and development [1-5]. 
Based on the theories, it can synthesize that in an educational institution, teachers' Organizational Citizenship Behavior (OCB) is OCB is a teachers assessment towards their behavior in carrying out their job duties voluntarily and exceed the work requirements set by the organization and measured by using a customized questionnaire based on the following indicators: 1) altruism, 2) conscientiousness, 3) sportsmanship, 4) courtesy, 5) civic.

Leadership is an activity carried out by a leader to influence others' behavior or change to achieve the desired goals. A leader needs an effective leadership style to successfully influence and change others' behavior [6]. Servant Leadership is a form of leadership style.

Servant Leadership is a serving behavior that arises from an individual's desire to voluntary help team member to grow, independent, healthy, build trust, and have a serving spirit. This behavior has the following indicators: (1) empowering and developing abilities, potential, self-confidence and mental strength, (2) humanity; respecting others, (3) authenticity; express themselves according to their identity, communicating honestly and openly, (4) providing direction; understanding that the focus of their behavior is in line with organizational goals and expectations, (5) stewardship; obedience to carry, empathy and healing, helping people with psychological problems, (6) altruism, helping and sacrificing for other individuals [7-9].

Servant leader acts as a servant, putting others' need as priority, helping them to grow, develop team member to achieve the organization's goals. They perceive team member as their colleagues, aim to work together with them. The indicators are (1) value people, respect and prioritize the interests of subordinates, (2) develop people; provide opportunities for a team member to develop themselves, (3) build community; build collaboration with a team member, (4) open to receiving input, (5) provide leadership; provide future views, take the initiative, and are competent, (6) share leadership [10].

Based on the above theories, it can synthesize that operational concept of servant leadership in this study is an assessment of teachers to their principal who owns it the behavior of serving the teacher as his/her subordinate and measured through a questionnaire adjusted based on indicators: 1) value people, 2) develop people, 3) build community, 4) display authentic, 5) provide leadership, 6) share leadership

Job satisfaction is an emotional response to someone's work that is influenced by 1) motivation, is an impulse of the will that causes a person to do an action to achieve specific goals, 2) commitment to the organization, that is an attitude that reflects the extent to which an individual knows and be bound to the organization, 3) absence, that is the situation that arises if an employee fails to come to work when the person is scheduled to work, 4) the stress as perceived by employee when he/she work. [11].
Job satisfaction is the attitude and emotional condition or personal feelings towards a job. Based on the assessment, his work can satisfy his needs and show the fit between expectations and explain how much sense of justice in his career. The indicators of job satisfaction are 1) The work itself; 2) Appreciation of duties (pay, salaries, benefit); 3) Promotion and personal development opportunities; 4) Relationships between colleagues and superiors; 5) Justice concerning duty, and 6) Supervision from superiors [12-16].

Based on the explanation of the theories above, it can be synthesized that job satisfaction is a teachers evaluation towards their feeling about their pleasant job and results from an assessment of the work and work experience that has been done and measured by using a customized questionnaire based on the following indicators: (1) the job itself, (2) salary, (3) promotion opportunities, (4) supervision from superiors (5) colleagues.

This condition drives us to study how OCB can increase by strengthening servant leadership and job satisfaction. Based on the literature review and evidence from prior researches above mentioned, it can be stated research hypotheses as follows:

- There is a positive relationship between servant leadership with OCB.

- There is a positive relationship between job satisfaction with OCB.

- There is a positive relationship between servant leadership and job satisfaction with OCB.

\section{METHODOLOGY}

This is a quantitative study that applied correlational method and used the questionnaires as intruments for data collecting. Descriptive statistics, quantitative and SITOREM analysis are used to find strategic to improve OCB. The population are all 145 private junior high shool teachers in South Bogor. The proportional random sampling, and Slovin formula was used to take 107 sample. Data and information was gathered by questionnaires of OCB (30 items), Servant leadership (33 items), and Job satisfaction (31 items). The questionnaires validity was tested by Pearson Product moment and the reliability was tested by Cronbach's alpha to be $91.1 \%$, $94.8 \%$ and $89.7 \%$ respectively. Multiple linear regression and hypothesis testing analysis is performed at a significance level of 0.05 using the Product-Moment Coefficient of Correlation. SITOREM analysis was used to determine applicative improvement recommendations priority that has the most impact on problem-solving strategies.

Analysis is conducted with multiple linear regression and hypothesis testing is performed at a significance level of 0.05 using Product-Moment Coefficient of Correlation. SITOREM analysis was used to determine priorities applicative improvement recommendations that have the most impact on problem-solving. 


\section{RESULT AND DISCUSSON}

Based on the results of hypothesis testing and data analysis, it was found that all variables have a significant positive effect on teachers OCB, in order based on the strength of influence as follows: Servant leadership and job satisfaction $\left(\mathrm{ry}_{12}=0.5581\right.$, $\rho<0.01$ ), Servant leadership (ry $1=0.5494, \rho<0.01)$, Job satisfaction $\left(\mathrm{ry}_{2}=0.4326, \rho<0.01\right)$

Table 1 is equipped with linear equations that can predict OCB variations based on changes in visionary leadership and job satisfaction.

TABLE I. CORRELATION SCORE SUMMARY

\begin{tabular}{|l|c|c|c|}
\hline Relation & $\mathbf{R}$ & Sig. level & Linear equation \\
\hline $\mathrm{Y}-\mathrm{X}_{1}$ & 0.5494 & $\rho<0.01$ & $\hat{\mathrm{Y}}=53,176+0.4649 \mathrm{X}_{1}$ \\
\hline $\mathrm{Y}-\mathrm{X}_{2}$ & 0.4326 & $\rho<0.01$ & $\hat{\mathrm{Y}}=40.631+0.5901 \mathrm{X}_{2}$ \\
\hline $\mathrm{Y}-\mathrm{X}_{1} \mathrm{X}_{2}$ & 0.5581 & $\rho<0.01$ & $\hat{\mathrm{Y}}=40.664+0.394 \mathrm{X}_{1}+0.176 \mathrm{X}_{2}$ \\
\hline
\end{tabular}

*Wulandari, Sunaryo, Sumardi, Tedjakusuma

\section{A. Servant Leadership and $O C B$}

Servant leadership is a principal's behavior as a leader who serves the teacher as his subordinate voluntarily and aims to develop themselves optimally and build cooperation between leaders and members. Interpersonal relationships with teachers as team members are the most important thing. Principals who serve with respect for teachers, develop the maximum potential for teachers, build cooperation between school principals and teachers, are open to receiving input, think ahead, and involve teachers in achieving the vision and mission of the organization, so teachers as subordinates can believe in servant leadership principal completely.

\section{B. Job Staisfaction and $O C B$}

Job satisfaction is an individual's feeling of a pleasant job and is the result of assessing the work and work experience he has done. Satisfaction is closely related to the aspect of feeling happy. Satisfaction and happiness can be realized when a teacher gets many positive things from the organization. The dimensions of adequate salary and rewards, teaching work itself, job promotion, and a comfortable work environment, including school principals and colleagues, support job satisfaction in schools. Teachers who get high job satisfaction will also show high OCB. Teachers will do their work voluntarily, exceeding the standards set by the organization. The teacher tries to complete work assignments as much as possible and on time. Even willing to work outside working hours. This is in line with the opinion of Schermerhorn, Osbon, Uhl-Bien, Huntwhich states that job satisfaction is closely related to OCB. [17]. A similar idea is expressed by Robbins and Jugde, who say that job satisfaction is the primary determinant of individual OCB [9]

\section{Servant Leadership, Job Satisfaction, and $O C B$}

The leadership of the principal who serves is a factor that provides positive job satisfaction for teachers as subordinates. The school principal voluntarily serves team members so that they have the opportunity to develop their potential to the fullest and can cooperate with subordinates and are open to receive input. This job satisfaction indicates a match between the expectations and reality obtained about his school organization's work. Teachers feel valued at work, and get a conducive work environment from school principals and colleagues, effective supervision from school principals, opportunities to develop personal potential, and fair salaries and promotions. The job satisfaction obtained encourages teachers to contribute by behaving OCB in school organizations

This conclusion is in line with Kreitner and Kinicki opinion that servant leadership is positively correlated with job satisfaction [16]. In line with this thought, job satisfaction is also proven to be correlated with OCB, as stated by Robbins and Jugde, that job satisfaction is correlated with OCB. These findings show that Organizational Citizenship Behavior (OCB) of private junior high schools (GTY) private junior high schools in Bogor Selatan District can improve through leadership development efforts to serve school principals and teacher job satisfaction.

It can conclude that the Organizational Citizenship Behavior (OCB) of private junior high schools in the South Bogor District can improve through leadership development efforts to serve school principals and teacher job satisfaction.

\section{The SITOREM Analysis}

The Scientific Identification Theory to Conduct Research in Education Management (SITOREM) analysis identifies, analyzes, assesses, and prioritizes the indicators of research variables that need to be corrected or maintained immediately. The analysis stage is carried out using operations in education management [18]. Furthermore, Sunaryo and Setyaningsih suggest that in correlational research, the SITOREM analysis method is used to 1) identify the strength of the relationship between the independent variable and the dependent variable, 2) analyze the indicator value of the research variable derived from the research score, 3) analyze the weight of each indicator of each variable based on four criteria: cost (sacrifice expended by the organization), benefit (usefulness for the organization), Urgency (urge to obedience in the organization), and importance (the level of importance of these indicators for the organization). [19].

This study found that the most strength relationship is between Servant Leadership and Job satisfaction together with OCB (ry12 $=0.5581, \rho<0.01$, and the relationship between Servant leadership with OCB is stronger than relationship between Job satisfaction with OCB. These findings indicate that the priority for improvement is on the servant leadership variable indicators. Table 2 . shows the next stage, which is determining each indicator's weight, referring to expert judgment on the cost, benefit, urgent, and importance of all hands. This weight is related to the mean score of each indicator. Indicators with a score below four are suggested to improve, while a mean above four is recommended to maintain 
TABLE II. SITOREM ANALYSIS RESULT

\begin{tabular}{|c|c|c|c|c|c|c|}
\hline No & $\begin{array}{l}\text { Variable - } \\
\text { Indicators }\end{array}$ & Average & Weight & $\begin{array}{c}\% \\
\text { Weight }\end{array}$ & Recom & Priority \\
\hline \multicolumn{7}{|c|}{ SERVANT LEADERSHIP $(r=0,5494)$} \\
\hline 1 & Value people & 3.7 & 11 & 14 & $\mathrm{NI}$ & 3 \\
\hline 2 & Develop people & 4.1 & 15 & 21 & $\mathrm{M}$ & 1 \\
\hline 3 & Build community & 3.9 & 12 & 17 & $\mathrm{NI}$ & 4 \\
\hline 4 & Display authentic & 3.9 & 8 & 11 & $\mathrm{NI}$ & 5 \\
\hline 5 & Provide leadership & 3.7 & 12 & 17 & $\mathrm{NI}$ & 2 \\
\hline \multirow[t]{2}{*}{6} & Share leadership & 3.4 & 14 & 20 & $\mathrm{NI}$ & 1 \\
\hline & & & 72 & 100 & & \\
\hline \multicolumn{7}{|c|}{ JOB SATISFACTION $(r=0,4326)$} \\
\hline 1 & The Job It-Self & 3.3 & 16 & 23 & $\mathrm{NI}$ & 6 \\
\hline 2 & Salary & 3.5 & 15 & 22 & $\mathrm{NI}$ & 7 \\
\hline 3 & Promotion & 3.7 & 14 & 20 & $\mathrm{NI}$ & 8 \\
\hline 4 & Supervision & 3.9 & 11 & 16 & $\mathrm{NI}$ & 9 \\
\hline \multirow[t]{2}{*}{5} & Co-Workers & 4.3 & 13 & 19 & $\mathrm{M}$ & 2 \\
\hline & & & 69 & 100 & & \\
\hline \multicolumn{7}{|c|}{ O C B (Dependent Variable) } \\
\hline 1 & Altruism & 3.4 & \begin{tabular}{l|l}
11 & \\
\end{tabular} & 19 & NI & 10 \\
\hline 2 & Conscientiousness & 3.7 & 10 & 18 & NI & 11 \\
\hline 3 & Sportsmanship & 3.7 & 12 & 21 & NI & 12 \\
\hline 4 & Courtesy & 4.1 & 14 & 24 & $\mathrm{M}$ & 3 \\
\hline 5 & Civic Virtue & 3.9 & 10 & 18 & NI & 13 \\
\hline 7 & & & 57 & 100 & & \\
\hline
\end{tabular}

Recom $=$ Recommendation

$N I=$ Need Improvement

$M=$ To be maintained

Based on the SITOREM analysis result, it can be suggested that research variable indicators need to be improved, in order of priority as listed in the Table 3 which contains data that describes a sequence of actions that can use as a guide for strategic and implementation steps to improve OCB. The description of this indicator is essential to limit the scope of corrective action that needs to implement.

TABLE III. INDICATORS THAT SHOULD BE IMPROVE

\begin{tabular}{|l|l|l|}
\hline No & \multicolumn{1}{|c|}{ Indicator } & \multicolumn{1}{c|}{ Indicator description } \\
\hline \multicolumn{2}{|c|}{ Servant Leadership } \\
\hline 1 & Shared leadership & Engage team member to setting goal \\
\hline 2 & Provide leadership & $\begin{array}{l}\text { Lead team member to be positively } \\
\text { productive }\end{array}$ \\
\hline 3 & Value people & Respect others \\
\hline 4 & Build community & Develop community to work and serve \\
\hline 5 & Display authentic & Honestly open to others \\
\hline 6 & The job it-self & Job Satisfaction \\
\hline 7 & Salary & Perception about work and responsibility about salary and benefit \\
\hline 8 & Promotion & Perception about carrier growth opportunity \\
\hline 9 & Supervision & $\begin{array}{l}\text { Perception about supervision, support and } \\
\text { coaching from leader }\end{array}$ \\
\hline 10 & Altruism & $\begin{array}{l}\text { Voluntary helping team member to get } \\
\text { solution on his/her job problem }\end{array}$ \\
\hline 11 & Conscientiousness & $\begin{array}{l}\text { Concern about using time and resources } \\
\text { efficiently }\end{array}$ \\
\hline 12 & Sportsmanship & $\begin{array}{l}\text { Tolerance toward unsatisfactory condition } \\
\text { without complain }\end{array}$ \\
\hline 13 & Civic Virtue & $\begin{array}{l}\text { Responsible, wise, and loyal to organization } \\
\text { condition and development }\end{array}$ \\
\hline
\end{tabular}

*Wulandari, Sunaryo, Sumardi, Tedjakusuma

\section{CONCLUSIONS}

This study has succeeded in identifying indicators of research variables that need to be improved or explicitly maintained, significantly to improve teachers' OCB. These findings will make it easier for school principals to design priority strategies for improving OCB by the availability of resources in schools.

To improve teacher OCB, school principals must invite teachers to set school goals and targets actively. This activity also makes teachers feel more meaningful because they do more strategic things for schools. When taking part in setting school goals, conscientiousness will increase because they will become more concerned about using time and resources more efficiently.

OCB can be improved if the principal is more honest, open, respectful of the teacher, which, if accompanied by practical guidance and supervision, will increase civic virtue where teachers are more responsible, wise, and loyal to contribute optimally in every school development.

Strategies to increase teacher job satisfaction through more significant opportunities for promotion and benefits from schools, combined with effective direction from school principals so that teachers can be more productive, are expected to impact OCB significantly.

Because this study is limited to 3 independent variables, further research can elaborate on the impact of other factors such as organizational culture or organizational commitment using a different approach such as mix-methods to deepen the result.

\section{REFERENCES}

[1] S.H. Maulana and W. Sunaryo, Sequential Explanatory Analysis on Lectures' Work Quality investigated from Organizational Citizenship Behavior, Innovativeness, anf Training Effectiveness. "International Journal of Multidisiplinary Education and Research", Volume 3, Issue 3, pp. 84-87. 2018.

[2] A. Suzana, Pengaruh Organizational Citizenship Behaviour (OCB) terhadap Kinerja Karyawan. "Jurnal Logika". 19(1), 42-50. 2017.

[3] N. Jahangir, M.M. Akbar, M. Haq, Organizational Citizenship Behaviour. Its Nature and Antecendents. "BRAC University Journal". 01(2).pp. 75-85. 2004.

[4] S. Tambe and M. Shanker, A Study of Organizational Citizenship Behaviour (OCB) and Its Dimensions: A literature Review. "International Research Journal of Business and Management". 1, 67-73. 2014.

[5] J.A. Colquitt, J.A. Lepine, and M.J. Wesson, "Organizational Behaviour: Improving Performance and Comittment in the Workplace". New York: Mc Grow Hill Education. pp.39-41. 2015.

[6] W. Sunaryo, "Instrumen Pengukuran Gaya Kepemimpinan: Konsep dan Metode Pengukuran Gaya-gaya Kepemimpinan yang Efektif untuk Mengelola Kondisi dan Situasi Organisasi yang Spesifik". Bogor: Yayasan Warkat Utama. ISBN: 9786026090904. p.12. 2017.

[7] D. Van Dierendonck, Servant Leadership: A review and Synthesis. "Journal of Management". 37(4) 1228-1261. 2011.

[8] G. Yukl, Leadership in Organizations. New Jersey: Pearson Education, Inc. 2010.

[9] S. Robbins and T.A. Judge, "Perilaku Organisasi. Terjemahan Ratna Saraswati dan Febriella Sirait”. Jakarta: Penerbit Salemba. p.267. 2015. 
[10] J.A. Laub, "Defining Servant Leadership: A Recommended Typology for Servant Leadership Studies". Indiana Wesleyan University. p.9. 2004.

[11] S.H. Mardhiah and W. Sunaryo, Analyze of Organizational Culture, Transformational Leadership, Job Satisfaction toward Organizational Commitments with Sequential Explanatory Method. "International Journal of Multidisciplinary Education and Research", Volume 3, Issue 4, pp. 36-39. 2018.

[12] B.T. Nurcahya and M. Tukiran, Analysis of Sequential Explanatory on Organizational Commitment Reviewed from Organizational Culture, Transformational Leadership, and Work Satisfaction. "International Journal of Innovative Research in Science, Engineering and Technology", Volume 6, Issue 8, pp. 17437-17441. 2017.

[13] J.L. Gibson, J.H. Donelly Jr, J.M. Ivancevich, and R. Konopaske, "Organizations: Behaviour, Structure, Process". New York: Mc Grow Hill. 2012.
[14] M. Shaju and D. Subhashini, A study on the impact of Job Satisfaction on Job Performance of Employees working in Automobile Industry, Punjab, India. "Journal of Management Research". 9(1), 117-130. 2017.

[15] E. Edison, Y. Anwar, and I. Komariyah, "Manajemen Sumber Daya Manusia". Bandung: CV Alfabeta. 2018

[16] R. Kreitner \& A. Kinicki, "Organizational Behaviour". 9TH Edition. New York: McGraw- Hill. p.494. 2010.

[17] J.R. Schermerhorn Jr., R.N. Osborn, M. Uhl-Bien, and J.G. Hunt, "Organizational Behaviour". 12th edition. New York: John Wiley \& Sons, Inc. p. 67. 2012

[18] S. Hardhienata, The Development of Scientific Identification Theory to Conduct Operation Research in Education Management (SITOREM). "IOP Conference Series: Materials Science and Engineering". Vol. 166. 2017.

[19] W. Sunaryo and S. Setyaningsih, "Peningkatan Kualitas Layanan Melalui Pengembangan Organizational Citizenship Behavior, Keinovatifan, dan Efektivitas Pelatihan". Bogor: Yayasan Warkat Utama. ISBN: 9786020740034. 2019. 